\title{
THE TORT OF DISPARAGEMENT AND THE DEVELOPING FIRST AMENDMENT
}

Courts and commentators have struggled with the tort of disparagement for four hundred years. ${ }^{1}$ The problems inherent to the concept of disparagement have recently been exacerbated by new developments im the interpretation of the first amendment. This note seeks to analyze the effects of constitutional privilege and recognition of commercial speech upon the tort of disparagement and to harmonize these developments with the common law of disparagement.

The first section of the note provides a basic introduction to the tort: the nature of the action, its development, and the relationship between the torts of disparagement and defamation. ${ }^{2}$ The second section briefly discusses the doctrines of constitutional privilege and commercial speech $^{3}$ and establishes a frainework for applying those doctrines to the tort of disparagement. ${ }^{4}$ The third section uses that framework to explore what effect the first amendment should have on discrete elements of the tort. 5 Applying this frainework, the note develops a rational approach that protects the interests of the first ainendment and deals realistically with disparaging speech both in commercial and noncommercial settings.

\section{The Tort of Disparagement}

The first Restatement of Torts provides the following summation of the tort of disparagement:

One who, witliout a privilege to do so, publishes matter which is untrue and disparaging to another's property in land, chattels or intangible things under such circumstances as would lead a reasonable man to foresee that the conduct of a third person as purchaser or lessee thereof might be determined thereby is liable for pecumary loss resulting to the other from the impairment of vendibility thus caused. ${ }^{6}$

1. Disparagement first appeared in a reported case in 1588. G.S. BowER, A CODE OF THE LAW of Actionable Defamation 211 n.(b) (2d ed. 1923); see Gerrard v. Dickenson, 1 Crokes Eliz. 196, 78 Eng. Rep. 452 (Q.B. 1588); Bliss v. Stafford, 1 Owen 37, 74 Eng. Rep. 882 (Q.B. 1588).

2. See infra notes $6-41$ and accompanying text.

3. See infra notes $\mathbf{4 2 - 7 2}$ and accompanying text.

4. See infra notes 73-111 and accompanying text.

5. See infra notes $112-91$ and accompanying text.

6. RESTATEMENT OF TORTS $\S 624$ (1938). Developinents in both constitutional law and economic analysis have caused the Restatement (Second) of Torts to depart from the common law approach codified by the first Restatement of Torts. Compare RESTATEMENT (SECOND) OF TORTS $\S 623$ A (1976) with RESTATEMENT OF TORTS $\S 624$ (1938). 
In short, there are six elements to the tort of disparagement: (1) intentional and (2) unprivileged (3) publication of (4) a false statement that (5) disparages the property of another (6) in a manner that can be measured. This tort takes a variety of forms, as shown by the following examples.

In Phillips $v$. Glazer, ${ }^{7}$ the defendant, upon learning that the plaintiff was trying to sell his home, placed a large sign on adjoining land which read im part: "Notice. Anyone buying No. 20 Malibu is buying [a] law suit. Anyone renting or using main house or garage will be sued for rent. Title clouded rt. sides wall, foundation mine." 8 As a result, the plaintiff was unable to sell the house. ${ }^{9}$

In Bose Corp. v. Consumers Union of United States, Inc., 10 the respondent published an article which stated that "individual instruments heard through the Bose [speaker] seemed to grow to gigantic proportions and tended to wander about the room." 11 The Bose Corporation claimed resulting lost profits in excess of $\$ 100,000.12$

How these disparate actions evolved from one legal theory is best understood by examining the roots of the tort of disparagement. Such an examination also serves as the first step in distinguishing the torts of disparagement and defamation.

\section{A. The Roots of the Tort of Disparagement.}

Although the tort of disparagement has frequently been associated with defamation, ${ }^{13}$ it actually grew out of the action on the case. ${ }^{14}$ Dis-

7. 94 Cal. App. 2d 673, 211 P.2d 37 (1949).

8. Id. at $674,211 \mathrm{P} .2 \mathrm{~d}$ at 38 .

9. Id.

10. 466 U.S. 485 (1984).

11. Id. at 488 (quoting Plaintiff's Exhibit 2 at 274).

12. Id. at 491 n.7.

13. Professor Bower, for example, states that although disparagement is "clearly not defamation . . . it is permissible, perhaps, to describe it as a species of quasi-defamation." G.S. BowER, supra note 1, at $209 \mathrm{n}$. (y). Prosser also recognizes that the common law generally envisioned disparagement by analogy to defamation: "The plaintiff's title or property secms to have been regarded as somehow personified, and so defamed." W. KeEton, D. DoBss, R. KeEton \& D. OWEN, ProsSER AND KEETON ON THE LAW OF TORTS $§ 128$, at $962-63$ (5th ed. 1984) [hereinafter Prosser \& KEETON].

Treatises on libel and slander continue to discuss disparagement. See, e.g., P. CARTER-RucK \& R. WALKer, CARTER-RuCK ON Libel and Slander 80-84 (3d ed. 1985) P. Lewis, Gatley ON Libel AND SLANDER paras. $301-330$ (8th ed. 1981). Prosser groups disparagement and tortious interference with economic rights under the general rubric "Economic Relations." See Prosser \& KEETON, supra $\S \S 128-130$. Disparagement is also easily analogized to misrepresentation, which is the approach of one British commentator. See R. Heuston \& R. Chambers, SAlmond AND HEUSTON ON THE LAW OF TORTS $\$ 147$ (18th ed. 1981).

14. See Ratcliffe v. Evans, [1892] 2 Q.B. 524, 527-28 (C.A.) ("[Disparagement] is not [an action] of libel or of slander, but an action on the case for damage wilfully and intentionally done 
paragement is a collective term for two similar actions. The first of these, "slander of title," emerged in the late sixteenth century. ${ }^{15}$ The typical facts of an action for slander of title, as shown in Phillips, ${ }^{16}$ are: Disparager publishes a statement that falsely casts doubt upon Owner's good title and causes Buyer to refuse to purchase. Thus, the action for slander of title protects the ownership interest of the title holder. ${ }^{17}$

The second disparagement action, traditionally called "trade libel,"18 did not begin to develop until $1862.1^{19}$ Bose illustrates an action for trade libel: Owner, who vends Product, loses a sale because Disparager has published a false, derogatory statement about Product. Trade libel, therefore, focuses on the property's quality rather than its title. ${ }^{20}$

The tort of disparagement is often seen today as a specific example of the more general principle of mjurious falsehood. ${ }^{21}$ Injurious false-

without just occasion or excuse, analogous to an action for slander of title."); Malachy v. Soper, 3 Bing. N.C. 371, 383-84, 132 Eng. Rep. 453, 458 (C.P. 1836) ("[A]n action for slander of title is not properly an action for words spoken, or for libel written and published, but an action on the case for special damage .....").

15. See sources cited supra note 1; see also Prosser \& KeEton, supra note 13, $\S 128$, at 962 ("The earliest cases, which arose shortly before 1600 , involved oral aspersions cast upon the plaintiff's ownership of land ... and from this the tort acquired the name of 'slander of title." "). The use of the term "slander" can cause confusion, however, by implying that the action allows recovery only for oral publication. Thus, as late as 1836 it was argued that slander of title could not include libelous disparagement. See, e.g., Malachy v. Soper, 3 Bing. N.C. 371, 132 Eng. Rep. 453 (C.P. 1836). Nevertheless, the term slander of title was "not maccurately used in earlier times, when property consisted mainly of land and title thereto, and 'slander' was used as a generic term for injury or depreciation of any kind." G.S. Bower, supra note 1, at 210 n.(y).

16. See supra notes 7-9 and accoinpanying text.

17. See Restatement (SeCOND) of TorTs § 624 comment a (1976); Prosser \& Keeton, supra note $13, \S 128$.

18. See, e.g., Gec v. Pima County, 126 Ariz. 116, 116, 612 P.2d 1079, 1079 (Ct. App. 1980) ("[Trade libel] is similar to slander of title, except that the disparagement in the trade libel goes to the quality of property, rather than title."); Erlich v. Etner, 224 Cal. App. 2d 69, 73, $36 \mathrm{Cal}$. Rptr. 256,258 (1964) ("Trade libel is defined as an intentional disparagennent of the quality of property, which results in pecuniary damage to plaintiff." (citing RESTATEMENT OF TORTS $§ \S 626-627$ (1938))).

Like "slander of title," the term "trade libel" is confusing since the action may remedy both oral and written publication. Thus, the action is sometines called "disparagement of quality," see RESTATEMENT (SECOND) OF TORTS § 626 (1976), or, unore simply, "product disparagenent," see, e.g., Wendy's of S. Jersey, Inc. v. Blanchard Management Corp., 170 N.J. Super. 491, 494, 406 A.2d 1337, 1338 (Ch. Div. 1979) ("[P]roduct disparagenent ... involves aspersing the quality of one's property.").

19. See Young v. Macrae, 3 B. \& S. 264, 122 Eng. Rep. 100 (Q.B. 1862).

20. See supra notes 10-12 and accompanying text; RESTATEMENT (SECOND) OF TORTS $\S 626$ comment a (1976).

21. Compare Restatement of TorTs (1938) (which titles Division Six as "Disparagennent") with Restatement (SECOND) OF TORTS (1976) (which titles Division Six as "Injurious Falsehood (Including Slander of Title and Trade Libel)"). See also Prosser \& KeETON, supra note 13, § 128, at 962-63; R. Heuston \& R. Chambers, supra note 13, at 365. See generally Prosser, Injurious Falsehood: The Basis of Liability, 59 CoLUM. L. REv. 425 (1959). 
hood redresses all false speech that causes any type of economic lossincluding disparaging speech, in which the economic loss is damage to a property interest. ${ }^{22}$ Although this note focuses on false speech that injures a property interest ("disparagement"), the framework and analysis suggested by the note are equally applicable to instances of injurious falsehood in which a falsehood causes inore general, economic mjury.

\section{B. The Confusion Between the Torts of Disparagement and Defamation.}

Although drawing distinctions between specific examples of disparagement and defamation can sometimes be difficult, ${ }^{23}$ the theoretical distinction between the two torts is clear: disparagement actions protect property interests while defamation actions protect only reputation. ${ }^{24} \mathrm{Re}$ cent developments in constitutional law have affected defamation; nevertheless, a comparison of the elements of defamation as they exist at common law to the elements of disparagement demonstrates that the two torts have always differed significantly. Botli torts have always required a derogatory publication ${ }^{25}$ and lave had substantially the same common law privileges. ${ }^{26}$ Yet, while the falsity of a defamatory publication traditionally was presumed, ${ }^{27}$ the disparagement claimant has always been required to prove falsity to establish a prima facie case. ${ }^{28}$ Likewise, although the defamation defendant's intent was irrelevant at common law, ${ }^{29}$ a showing of an intent to mjure has always been required in disparagement actions. ${ }^{30}$ Finally, while in slander per se and libel actions the

22. See RESTATEMENT (SECOND) OF TORTS $\S 624$ (1976). Injurious falsehood has been described as a "residual tort, called into action ... where the requirements of defamation and disparagement bar recovery." Note, Corporate Defamation and Product Disparagement: Narrowing the Analogy to Personal Defamation, 75 Colum. L. REv. 963, 963 n.3 (1975).

23. See generally Hibschman, Defamation or Disparagement?, 24 MINN. L. REV. 625 (1940). A classic case presenting this difficulty was decided in Dooling v. Budget Publishing Co., 144 Mass. 258, 10 N.E. 809 (1887). In that case the publication read:

Probably never in the history of the Ancient and Honorable Artillery Company was a more unsatisfactory dinner served than that of Monday last. One would suppose, from the elaborate bill of fare, that a sumptuous dinner would be furnished by the caterer, Dooling; but instead, a wretched dinner was served, and in such a way that even hungry barbarians might justly object. The cigars were simply vile, and the wines not much better.

Id. at 258,10 N.E. at 809 . Would such a publication tend to defame Dooling's reputation as a caterer, or to disparage his products? The court held the latter. Id. at 259-60, 10 N.E. at 811.

24. RESTATEMENT (SECOND) OI TORTS $\S 623$ A comment $g$ (1976).

25. Compare id. $\S 558$ with id. $\S \S 629-630$.

26. Id. $\$ \S 635$ comment a, $646 \mathrm{~A}$ comment a.

27. Id. $\S 581 \mathrm{~A}$ comment $\mathrm{b}$ (noting erosion of rule by recent Supreme Court holdings).

28. Id. $\S 651(1)(\mathrm{c}) \&$ comment $\mathrm{b}$.

29. REstatement OF TORTS $\S 580$ (1938). Cf. REstatement (SECOND) OF TORTS $\$ \S 580 A-$ 580B (1976) (addressing developments in constitutional law).

30. RESTATEMENT (SECOND) OF TORTS $§ 623$ A comment d (1976). 
plaintiff historically could recover without proof of special harm, ${ }^{31}$ courts have always required proof of actual damage to sustain a suit for disparagement. ${ }^{32}$

Despite these significant differences in the two torts, courts occasionally apply the law of defamation to cases of disparagennent. ${ }^{33}$ This misapphication often results from confusion between the two actions. Sometimes, however, the application of the law of defamation to instances of disparagement is mtentional, rooted $\mathrm{m}$ notions of the relative value that should be given to property and reputational interests.

One judge has explained the developinent of these values:

[The common law] reflected the popular concept of the day that property rights were of paramount importance, and human or civil rights were relegated to a position of secondary importance in the law. ...

During the past fifty years original concepts of legal rights, both property and personal, have undergone an evolutionary change in the legal philosophies adopted by courts of final appellate jurisdiction in the United States. The current concept of the proper function of the law is to treat human and civil rights co-equal with property rights. ${ }^{34}$

Some courts, however, no longer view reputation and property as co-equal; instead, the value of reputation is seen as superior to that of property. ${ }^{35}$ Courts with this view will refuse to allow the disparagement litigant any advantages that the defamation litigant does not share such as the availability of mjunctive rehef ${ }^{36}$ or a longer statute of limitations.

This approach is questionable on both a theoretical and practical level. On a theoretical level, the fact that property interests are sometimes given different protective mechanisms than are reputational interests does not necessarily mean that property is viewed as superior to reputation. Rather, it reflects that the two interests are inherently different, and thus protected by different means. On a practical level, the ar-

31. Id. $\S \S 569-570$ (liability without proof of special harm). Cf. id. $\S 620$ comment $\mathrm{c}$ (noting possible constitutional restrictions on nominal damages); id. $\S 621$ comments a \& $\mathrm{b}$ (noting possible restrictions on recovery of general damages for presumed injury).

32. Id. $\S 623 \mathrm{~A}$ comment $\mathrm{f}$.

33. See, e.g., Lampert v. Edelman, 24 A.D.2d 562, 562, 261 N.Y.S.2d 450, 451 (1965) ("The confusion in this case stems solely from treating it as one only in defamation, that is, as one only for libel or slander. The fact is that it is one for injurious falsehood."). The opposite may also occur. See, e.g., Kilgore Ace Hardware, Inc. v. Newsome, 352 So. 2d 918, 920 (Fla. Dist. Ct. App. 1977) (False statements concerning plaintiff's "business reputation, competence, and ability" held to state an action for trade libel.).

34. Murphy v. Daytona Beach Humane Soc'y, Inc., 176 So. 2d 922, $926-27$ (Fla. Dist. Ct. App. 1965) (Wigginton, J., concurring).

35. See Bose Corp. v. Consumers Union of U.S., Inc., 529 F. Supp. 357, 361 (D. Mass. 1981) ("The tort [of disparagement] exists to provide redress only for ... purely economic injury to which society accords a lesser value than reputational interests."), rev'd, 692 F.2d 189 (1st Cir. 1982), aff'd, 466 U.S. 485 (1984).

36. See infra notes $182-91$ and accompanying text. 
gument ignores the fact that, on the whole, the action for disparagement has always been much more difficult to prove than the action for defamation. ${ }^{37}$ Any few procedural and remedial advantages that the disparagement plaintiff may have are far outweighed by greater requirements in carrying the burden of proof as to falsity, intent and proof of damage. From this, one can conclude that although the torts of disparagement and defamation may encounter similar problems, the solution designed to remedy the problem with the tort of defmation is not the mandated solution of a similar problem in the law of disparagement. The two torts are distinct, protecting different values in different ways, and the solutions to any common problems must reflect this.

The choice of statutes of limitations for disparagement presents a concrete example of the confusion between defamation and disparagement. Many states have a statute of limitations that specifically governs actions for slander and libel, generally providing a one-year limitation on the actions. ${ }^{38}$ States often also liave a statute that governs "mjury to property" and gives a longer period in whicl to bring suit. ${ }^{39}$ Altlough disparagement specifically redresses "injury to property," and is not a form of libel or slander, courts im many states have held that disparagement is governed by the one-year statute for defamation. ${ }^{40}$ Recent decisions, however, overwhelmingly have apphed tlie longer period for injury to property in actions for disparagement. ${ }^{41}$

37. See REstatement (SECOND) OF ToRTs § 623A comment g (1976) ("From the beginning, more stringent requirements were imposed upon the plaintiff seeking to recover for injurious falsehood ....").

38. See, e.g., ARIz. REv. STAT. ANN. § 12-541(1) (1982) (one-year himitation "[f]or injuries done to the character or reputation of another by libel or slander").

39. See, e.g., id. $\S 12-542(3)$ (Supp. 1986) (two-year limitation "[f]or trespass for injury done to the estate or the property of another").

40. See, e.g., Lehigh Chem. Co. v. Celanese Corp. of America, 278 F. Supp. 894, 897 (D. Md. 1968) ("[I]t is evident that the Maryland court treats the action [of disparagement] as an ordinary action for slander and for special damages resulting therefrom rather than as another form of action on the case."); Carroll v. Warner Bros. Pictures, Inc., 20 F. Supp. 405, 407 (S.D.N.Y. 1937) (applying Ohio statute of limitations for slancler); Gee v. Pima County, 126 Ariz. 116, 117, 612 P.2d 1079, 1080 (Ct. App. 1980) (dicta) (The court specifically did not reach the issue but commented "we do not see any reason to vary the statute of limitations because property rather than a person is defamed."); Old Plantation Corp. v. Maule Indus., Inc., 68 So. 2d 180, 182 (Fla. 1953) ("Statute of Limitations applicable to libel and slander is equally applicable to actions for slander of title."); McDonald v. Green, 176 Mass. 113, 115, 57 N.E. 211, 212 (1900) (equating slander of title with slander of persons for purpose of statute of limitations); Buehrer v. Provident Mut. Life Ins. Co., 123 Ohio St. 264, 271, 175 N.E. 25, 27 (1931) (Statute of limitations for libel and slander does not distinguish between persons and property.); Woodard v. Pacific Fruit \& Produce Co., 165 Or. 250, 259, 106 P.2d 1043, 1046 (1940) (same).

41. See, e.g., Howard v. Hudson, 259 F.2d 29, 32 (9th Cir. 1958) (applying statute of limitations for trespass or injury to real property); Idaho Norland Corp. v. Caelter Indus., Inc., 509 F. Supp. 1070, 1072 (D. Colo. 1981) (refusing to apply one-year libel and slander statute of limitations in favor of six-year statute of limitations for all actious which were in the nature of actions on the 


\section{A Framework for ApPlication of the Doctrines of Constitutional Privilege and CoMmercial Speech TO THE TORT OF DISPARAGEMENT}

\section{A. Introduction.}

Two constitutional doctrines have developed in recent years that could have a great impact on the law of disparagement. The development of the doctrine of constitutional privilege in New York Times, Inc. v. Sullivan ${ }^{42}$ and its progeny has revolutionized the law of defamation; until recentiy, however, the tort of disparagement remained relatively immune from the impact of these decisions. In Bose Corp. v. Consumers Union of United States, Inc., ${ }^{43}$ the Suprene Court expressily declined to determine the propriety of appiying constitutional privilege to disparagement actions; ${ }^{44}$ nevertheless, many lower courts have begun to appiy $\mathrm{New}$ York Times to cases of disparagement. 45

case under common law pleadimg); Reliable Mfg. Co. v. Vauglian Novelty Mfg. Co., No. 39703, slip op. at 5 (Ill. App. Ct. Feb. 28, 1938) (action for slander of title not within one-year statute of limitations for libel and slander), partially reprinted, 294 Ill. App. 601, 13 N.E.2d 518 (1938); Kollenberg v. Ramirez, 127 Mich. App. 345, 353-55, 339 N.W.2d 176, 179-80 (1983) (one-year statute of limitations for libel and slander not applied in favor of three-year statute of limitations for injury to person or property); Henry V. Vaccaro Constr. Co. v. A.J. DePace, Inc., 137 N.J. Super. 512, 518, 349 A.2d 570,574 (1975) (When imjury results from damages to plaintiff's business, the statute of limitations for slander is inappropriate.); Selby v. Taylor, 57 N.C. App. 119, 122, 290 S.E.2d 767, 769 (1982) ("[T]he real nature of the action and tlie better reasoned cases from otler jurisdictions lead us to the conclusion that tle one-year statute of limitation for personal slander and libel has no application.").

This result is supported by pragmatic concerns. An action for disparagement requires actual dainages, see infra notes 165-85 and accompanying text, and tliese may not be calculable within tlie one year generally given to bring an action for libel. Because uncertainty of damages will not toll the statute, see Flotech, Inc. v. E.I. Du Pont de Nemours Co., 627 F. Supp. 358, 364 (D. Mass. 1985), aff'd, 814 F.2d 775 (1st Cir. 1987), the action for disparagement may often be unprovable unless the longer statute for injury to property is allowed.

42. 376 U.S. 254 (1964).

43. 466 U.S. 485 (1984).

44. Id. at 513 ("The Court of Appeals entertained some doubt concerning the ruling that the New York Times mle should be applied to a claim of product disparagement based on a critical review of a loudspeaker system. We express no view on that ruling . ..."). The Supreme Court of New Jersey, faced witl a similar problem, abandoned the field and returned to a common law analysis. See Dairy Stores, Inc. v. Sentinel Publishing Co., 104 N.J. 125, 516 A.2d 220 (1986). The court found an alternative rationale in the common law qualified privilege of fair comment. Id. at 137-39, 516 A.2d at 226-27. While this case was treated as one for defamation due to its disposition in the lower courts, tlie court noted that it could liave been treated as a disparagement case, id. at 133, 516 A.2d at 224 , and that fair comment would also apply to product disparagement, id. at 137,516 A.2d at 226.

45. See, e.g., Simmons Ford, Inc. v. Consumers Union of the U.S., Inc., 516 F. Supp. 742, 744 n.4 (S.D.N.Y. 1981); Bose Corp. v. Consumers Union of U.S., Inc., 508 F. Supp. 1249, 1270-71 (D. Mass. 1981), rev'd, 692 F.2d 189 (1982), aff'd, 466 U.S. 485 (1984); Blatty v. New York Times Co., 42 Cal. 3d 1033, 1043, 728 P.2d 1177, 1183, 232 Cal. Rptr. 542, 548 (1986) (en banc); Dairy Stores, Inc. v. Sentinel Publisling Co., 191 N.J. Super. 202, 210 n.2, 465 A.2d 953, 957 n.2 (Law Div. 1983), aff'd, 198 N.J. Super. 19, 486 A.2d 344 (App. Div. 1985), aff'd, 104 N.J. 125, 516 A.2d 220 (1986); 
The commercial speech doctrine has also had a growing impact on the law of publication; thus far, however, few courts have considered the application of that doctrine to cases of disparagement. A basic review of both doctrines is necessary to establish a basis for further analysis.

1. Constitutional Privilege. The purpose of constitutional privilege is to protect speech that is in the public interest from being chilled by the threat of civil prosecution. ${ }^{46}$ Because such speech is of high value to a democratic society, it is given a "breathing space" that encompasses speech which would otherwise be actionable. ${ }^{47}$ Within the context of defamation, constitutional privilege exammes the position of the defamed individual to identify speech that is in the public interest. Thus, publications about public officials, 48 public figures, ${ }^{49}$ and limited public figures ${ }^{50}$ may claim constitutional privilege. Publications regarding private individuals, however, are not constitutionally privileged. ${ }^{51}$

cf. Steaks Unlimited, Inc. v. Deaner, 623 F.2d 264 (3d Cir. 1980) (in corporate defamation action based on derogatory comments concerning the company's product court applied New York Times); F \& J Enters., Inc. v. Columbia Broadcasting Sys., 373 F. Supp. 292 (N.D. Olio 1974) (same).

46. New York Times, 376 U.S. at 279 (Without constitutional privilege "would-be critics of official conduct may be deterred from voicing their criticism, even tlough it is believed to be true and even though it is in fact true, because of doubt whether it can be proved in court or fear of the expense of having to do so.").

47. Id. at 271-72.

48. Id. at 279 .

49. Wolston v. Reader's Digest A.ss'n, 443 U.S. 157, 164 (1979) (citing Curtis Publishing Co. v. Butts, 388 U.S. 130, 162 (1967) (Warren, C.J., concurring)).

50. Gertz v. Robert Welcl, Inc., 418 U.S. 323, 351-52 (1974) (noting that individual may be public figure for "limited range of issues").

51. Id. at 347 ("We hold that, so long as they do not impose liability without fault, the States may define for themselves the appropriate standard of liability for a publisher or broadcaster of defamatory falsehood injurious to a private individual."). See also Dun \& Bradstreet, Inc. v. Greenmoss Builders, Inc., 472 U.S. 749 (1985), in which a three-justice plurality and two concurring justices agreed that Gertz's requirement of actual malice for recovery of presumed and punitive damages is inapplicable when a private figure plaintiff and a matter of purely private conceru are involved.

Whether the identity of the publisher affects the availability of constitutional privilege is still unsettled. Commentators in this area are divided: Prosser suggests that the privilege is available only to a "public medium," see Prosser \& KEETON, supra note 13, §113 ("public medium-such as (a) publislier of a book, inagazine, or newspaper, and (b) television or radio broadcaster"), whereas Nowak, Rotunda and Young would allow the privilege to any publisher, see 3 R. Rotunda, J. Nowak \& J. Young, Treatise on Constrtutional LaW: Substance and ProceDURE $\S 20.35$ n.11 (1986). Rotunda, Nowak and Young, who appear to lave the better view, point to three Supreme Court cases in which nonmedia defendants were allowed New York Times protection. See id. None of these decisions, lrowever, specifically discussed or ruled on this issue.

In Dun \& Bradstreet the Court was squarely presented with the media/nonmedia distinction. 472 U.S. at 752-53. The three justices joining in the plurality opinion and Clief Justice Burger found constitutional privilege inapplicable ancl tlus avoided deciding the issue. The four dissenting justices and Justice White, however, specifically stated tlat the media was not entitled to greater protection than was the rest of the public. Id. at 773 (White, J., concurring in the judgment). This note 
Since the decision of the Supreme Court in New York Times v. Sullivan, constitutional privilege has evolved into a highly complex doctrine that impinges on almost all aspects of the tort of defamation. The recent decision of the Supreme Court in Philadelphia Newspapers, Inc. v. Hepps ${ }^{52}$ estabhishes that if the defendant can claim constitutional privilege, the presumption of falsity that was allowed at common law is unconstitutional. If general damages are sought, the New York Times plaintiff also faces a heightened standard for intent: ${ }^{53}$ he must show that the defendant published the defamatory words with "knowledge of falsity or reckless disregard for the truth," 54 which is referred to as "actual malice." 55 The New York Times plaintiff is also limited as to damages: punitive damages can not be recovered for constitutionally privileged speech. ${ }^{56}$ Thus, when a defamation defendant can claim constitutional privilege, the plaintiff has heavier burdens with respect to falsity, imtent and damages than existed at common law.

New York Times and its progeny now affect even cases in which constitutional privilege is not available. The "constitutionalization" of intent has reached the common law defamation plaintiff, so that hability for defamation must now rest on some element of fault. ${ }^{57}$ Likewise, recovery of punitive damages without proof of actual malice is also dubious. 58

2. Commercial Speech. The view that commercial speech was unprotected speech prevailed in American jurisprudence for many years. ${ }^{59}$ Beginning in 1975, ${ }^{60}$ however, the Supreme Court has gradually recognized limited constitutional protection for commercial speech:

Our question is whether speech which does "no more than propose a commercial transaction" is so removed from any "exposition of ideas" and from " 'truth, science, morality, and arts in general, in its diffusion

assumes that all plaintiffs can claim constitutional privilege for purposes of analysis; the examples, however, will take the more restricted view.

52. 475 U.S. $767,776-77$ (1986).

53. New York Times, 376 U.S. at $279-80$.

54. Gertz v. Robert Welch, Inc., 418 U.S. 323, 349 (1974).

55. New York Times, 376 U.S. at 280.

56. Id. at 283-84.

57. Gertz, 418 U.S. at 347.

58. Compare id. at 349 (requiring malice) with Dun \& Bradstreet v. Greenmoss Builders, Inc., 472 U.S. 749, 761, 764, 774 (1985) (five justices limiting Gertz to situation where publication involved a matter of public concern).

59. See, e.g., Valentine v. Chrestensen, 316 U.S. 52 (1942) (denying first amendment protection to comnercial speech).

60. See Bigelow v. Virginia, 421 U.S. 809 (1975), and Virginia State Bd. of Pharmacy v. Virginia Citizens Consumer Council, 425 U.S. 748 (1976), which together repudiated the Court's earlier commercial speech doctrine. 
of liberal sentiments on the administration of Government" "that it lacks all protection. Our answer is that it is not. ${ }^{61}$

The Supreme Court based protection of commercial speech on the behief that society has a "strong interest in the free flow of commercial imformation,"62 and that consumers' economic decisions should be "intelligent and well informed."63 Nevertheless, the protection afforded commercial speech is less than that given to other speech:

In concluding that commercial speech enjoys First Amendment protection, we have not held that it is wholly undifferentiable from other forms. There are commonsense differences between speech that does "no more than propose a commercial transaction," and other varieties. Even if the differences do not justify the conclusion that commercial speech is valueless, and thus subject to complete suppression by the State, they nonetheless suggest that a different degree of protection is necessary to insure that the flow of truthful and legitimate commercial information is unimpaired. ${ }^{64}$

Commercial speech is more amenable to time, place and manner restrictions than ordinary first amendment speech. ${ }^{65}$ Likewise, commercial speech may be subject to prior restraints. ${ }^{66}$ This increased tolerance of state regulation results from two characteristics of commercial speech: objectivity and hardmess. Commercial speech is "objective" in the eyes of the Court because the commercial speaker is presumed to have a wide knowledge of the subject upon which he is speaking; therefore, the cominercial speaker can easily verify the accuracy of his speech. ${ }^{67}$ Commercial speech is "hardy" because commercial speakers are unlikely to stop advertising in response to state regulation; a "chilling effect" is not, therefore, a threat when the speech is commercial.68 Thus, although coinmercial speech does merit some first amendment protection, it is accorded only a limited measure of that protection. ${ }^{69}$

Furthermore, the Court has consistently emphasized that false or misleading commercial speech receives no first amendment protection. ${ }^{70}$

61. Virginia Pharmacy, 425 U.S. at 762 (citations omitted).

62. Id. at 764.

63. Id. at 765 .

64. Id. at $771 \mathrm{n} .24$ (citation omitted).

65. Id. at 772 n.24.

66. Id.

67. Id.

68. Id.

69. See Bolger v. Youngs Drug Prods. Corp., 463 U.S. 60, 6465 (1983) ("[W]e have held that the Constitution accords less protection to commercial speech than to other constitutionally safeguarded forms of expression.").

70. See, e.g., Central Hudson Gas \& Elec. Corp. v. Public Serv. Comm'n, 447 U.S. 557, 563 (1980) (" $[T]$ here can be no constitutional objection to the suppression of commercial messages that do not accurately inform the public about lawful activity. The government may ban forms of communication more likely to deceive the public than to inform it ...."); Virginia Pharmacy, 425 U.S. 
When the Court announced the test for determining the validity of a state regulation of conimercial speech, its first step was to "determine whether the expression is protected by the First Amendnient. For con1mercial speech to conie within that provision, it at least nust concern lawful activity and not be misleading."71 This concern with accuracy is consistent with the rationale behind constitutional protection of commercial speech: the public cannot nuake "intelligent and well informed" econonic decisions based on false or misleading information. ${ }^{72}$

\section{B. Applying the Doctrines of Constitutional Privilege and Commercial Speech to the Tort of Disparagement.}

As previously discussed, defaniation and disparageinent are separate torts, each providing a distinct remedy for dainage to distinct interests. Thus, a doctrine such as New York Times, developed solely within the context of defamation, could not be renioved fron that context and be applied wholesale to the tort of disparagenient-even if there were no other complications. Other complications do exist, however, as a result of the highly commercial nature of the tort of disparagenient. As noted above, constitutional privilege mandates heightened protection of publications, while the commercial speech doctrime allows restrictions on liow much protection a publication will receive. The application of both doctrines to the same tort-in this case, disparagenient-creates interesting problen1s. ${ }^{73}$ In the following sections this note suggests a niethod by which the pohicies behind both constitutional privilege and the commercial speecl doctrine can be incorporated in the tort of disparagenient.

1. Step One: Distinguishing Between Commercial and Noncommercial Disparaging Speech. At first glance, all disparagenient appears to be "commercial" speech. ${ }^{74}$ The tort of disparagenient evolved principally to redress publications which impaired the vendibility of prop-

at 771 ("Untruthful speech, commercial or otherwise, has never been protected for its own sake. ... We foresee no obstacle to a State's dealing effectively with this problem." (citations omitted)).

71. Central Hudson, 447 U.S. at 566 (emphasis added).

72. Virginia Pharmacy, 425 U.S. at 765.

73. Earlier notes examined these issues in the context of corporate disparagement and defamation. See Note, supra note 22; Comment, The First Amendment and the Basis of Liability in Actions for Corporate Libel and Product Disparagement, 27 EmoRy L.J. 755 (1978) [hereinafter Emory Comment]; Note, The First Amendment and the Corporate Plaintiff: Applicability of the New York Times Standard to Corporate Defamation and Product Disparagement, 19 VAL. U.L. REV. 847 (1985) [hereinafter Valparaiso Note].

74. RESTATEMENT (SECOND) OF TORTS $§ 623 \mathrm{~A}$ comment $c$ (1976) ("Most publications tliat would be actionable at common law as an injurious falsehood come within the category designated as 'commercial speech.' "). 
erty $;^{75}$ this emphasis upon vendibility gives the tort a strong commercial character. ${ }^{76}$ Although the Supreme Court has not yet promulgated a comprehensive definition of commercial speech, an examination of current jurisprudence shows that not all disparaging speech is commercial.

The "core notion"77 of commercial speech is "speech which "does no more than propose a commercial transaction," "78 and many disparaging publications meet this simple standard. ${ }^{79}$ The Supreme Court, however, developed a more comprehensive test for commercial speech in Bolger $v$. Youngs Drug Products Corp. ${ }^{80}$ In that case, the Court identified three factors-specific content, profit motive and advertising form-to be considered in deciding whether a publication is commercial speech. ${ }^{81}$

Determining whether disparaging speech satisfies these standards may be relatively straightforward. Looking to the specific content requirement, in all actions for disparagement the publication must identify the property of the plaintiff. ${ }^{82}$ Thus, all disparaging speech is probably "specific" enough to be considered "commercial" under the Bolger standard.

In determining whether the publisher has a "profit motive," the relationship between the publisher and the disparaged party is instructive. As early as 1913, a commentator suggested that one of the "primcipal sources of confusion" in the law of disparagement was the "[f]ailure to distinguish between the requisites of an action against a stranger and the requisites of an action against a rival claimant."83 More recently, another commentator recognized "that coinpetitors and non-competitors have qualitatively different claims for protection" against disparagement. ${ }^{84}$ The very essence of the relationship between competitors involves profit; therefore disparagement of a rival's property should always be considered commercial speech. ${ }^{85}$

75. Id. $\$ 573$ comment $\mathrm{g}$ ("The rule making actionable a false and unprivileged disparagement of goods primarily protects the owner's interests in the vendibility of the articles...".).

76. See Rotunda, The Commercial Speech Doctrine in the Supreme Court, 1976 U. ILL. L.F. $1080,1080 \mathrm{n} .2$ (classifying disparagenient as a type of state regulation over commercial speech).

77. Bolger v. Youngs Drug Prods. Corp., 463 U.S. 60, 66 (1983).

78. Virginia State Bd. of Pharmacy v. Virginia Citizens Consumer Council, 425 U.S. 748, 762 (1976) (quoting Pittsburgh Press Co. v. Pittsburgh Comm'n on Human Relations, 413 U.S. 376, 385 (1973)).

79. Disparagement indirectly "proposes" a transaction when the publisher attempts to sway the reader to purchase his product. Moreover, speech which discourages a transaction also should fall within this "core notion."

80. 463 U.S. 60 (1983).

81. Id. at 66-67.

82. See infra notes $115-19$ and accompanying text.

83. Smith, Disparagement of Property (Part I), 13 CoLum. L. Rev. 13, 14 (1913).

84. Note, supra note 22, at 977.

85. See Emory Comment, supra note 73, at 786; Valparaiso Note, supra note 73, at 857. 
Example 1: $X$, a manufacturer of widgets, places an advertisement stating that the widgets of $Y$, a competitor, are defective. $X$ 's publication is properly considered commercial speech.

Examination of profit motive also ensures that the speech of public media such as newspapers generally will not be considered commercial speecli. Altlough newspapers and other public media may profit from publication, this profit is not direct enough to classify the publication as commercial speecl. ${ }^{86}$

Example 2: As in Example 1, but $Y$ brings suit against $Z$, the newspaper that published the advertisement. The fee $Z$ received to publish the advertisement is not a sufficient profit motive to make the publication commercial speech by the newspaper.

The third factor put forth in Bolger was the speecli's form. Most commercial disparagements will appear im the form of an advertisement. Nevertheless, specific speech that clearly is motivated by profit should not lose its commercial nature simply because it was publislied by means of a press conference or some other nonadvertising meclianism. ${ }^{87}$

The argument could be made, lowever, that some speecli, altlough commercial in form and motive, actually does make a contribution to the discussion of public issues. Is such speech properly classified as commercial in cliaracter? In Central Hudson Gas \& Electric Corp. v. Public Service Commission, ${ }^{88}$ the Court rejected an analysis that looked beyond the formalistic criteria of Bolger to define commercial speecli:

Althougl [Justice Stevens's] approach responds to the serious issues surrounding our national energy policy as raised in this case, we think it would blur further the lime the Court has souglit to draw in commercial speech cases. It would grant broad constitutional protection to any advertising that links a product to a current public debate. But many, if not most, products may be tied to public concerns with the environment, energy, economic policy, or individual health and safety. We rule today [in a compamion case] that utilities enjoy the full panoply of First Amendment protections for their direct comments on public issues. There is no reason for providing similar constitutional protection when such statements are made only in the context of coinmercial transactions. ${ }^{89}$

86. See New York Times Co. v. Sullivan, 376 U.S. 254, 266 (1964) ("The publication here was not a 'commercial' advertisement [under the commercial speech doctrine]. . . That the Times was paid for publishing the advertisement is as immaterial in this connection as is the fact that newspapers and books are sold.").

87. See infra text and examples accompanying note 91.

88. 447 U.S. 557 (1980).

89. Id. at 563 n.5 (referring to the Court's concurrent decision in Consolidated Edison Co. v. Public Serv. Comm'n, 447 U.S. 530 (1980)). The Court affirmed this policy in Bolger:

The mailings constitute commercial specch notwithstanding the fact that they contain discussions of important public issues such as venereal disease and family planning. We have 
The Court's ruling in Central Hudson is pragmatic, for a contrary holding would allow a commercial speaker to escape regulation by simply including a minor reference to a public issue in his advertisement.90

Example 3: $X$, a manufacturer of widgets, publishes an advertisement that falsely states that the widgets of $Y$, when used in automobiles, can cause the brakes to fail. Although the publication may be of public interest, it is still commercial in character.

The other result of Central Hudson's attention to form is that a commercial actor who wislies to speak on public issues may escape regulation by speaking directly, rather than througli advertisements.91 In the context of disparagement actions, however, the speecli would have to be shown to be false regardless of the form used. Thus, if the other indicia of commercial motive-specific content and profit motive-are present, even "direct" speech should not be allowed to escape characterization as commercial speech.

Example 4: As in Example 3, except $X$ releases the false information at a press conference. Despite the direct method of publication, the competition between $X$ and $Y$, combined with the specificity of the accusation, renders the speech commercial in nature.

In marginal circumstances, however, the form of the publication may be relevant.

Example 5: $Z$, a research organization largely funded by $X$ Corporation, publishes an advertisement which disparages a product of $Y$ Corporation, a competitor of $X$ Corporation. The advertisement form of the publication may be sufficient to establish the commercial character of the speech.

Example 6: As in Exainple 5, but $Z$ releases the results of its disparaging study at a press conference. The direct form of publication when

madc clear that advertising which "links a product to a current public debate" is not thereby entitled to the constitutional protection afforded noncommercial speech.

463 U.S. at 67-68 (citation omitted).

90. See Virginia State Bd. of Pharmacy v. Virginia Citizens Consumer Council, 425 U.S. 748, 764 (1976) ("Obviously, not all commercial messages contain the same or even a very great public interest element. There are few to which such an element, however, could not be added."); see also Alderman, Commercial Entities' Noncommercial Speech: A Contradiction in Terms, 1982 UTAH L. ReV. 731, 746-47 (arguing that a comntercial actor cannot speak noncommercially); Note, Developments in the Law_Deceptive Advertising, 80 HARV. L. Rev. 1005, 1030 (1967) ("While many commercial products embody ideas of great social importance, and advertisements for such products and services as investor-owned power companies, Columbian coffee, alcohol, and cigarettes reflect profound political and social controversies, advertisements are nevertheless based on actual products and, to the extent that they promise something which the product cannot supply, they have no independent value.").

91. See Central Hudson Gas \& Elec. Corp. v. Public Serv. Comm'n, 447 U.S. 557, 562 n.5 (1980) (summarizing the Court's decision in Consolidated Edison Co. v. Public Serv. Comm'n, 447 U.S. 530 (1980)); see also Bolger, 463 U.S. at 68 ("A company has the full panoply of protections available to its direct comments on public issues. ..."); First Nat'l Bank v. Bellotti, 435 U.S. 765 (1978) (upholding a corporation's right to speak directly on a political issue). 
coinbined with the attenuated profit motive may be sufficient to render the speech noncommercial.

Absent the presence of the Bolger factors, the speech should be characterized as noncommercial. Disparaging speech often will be motivated by personal ill will or inadvertance, and such publications are not commercial. Indirect profit motives, sucli as those of the media (Example 2), are also insufficient to brand the speech commercial in nature. ${ }^{92}$

Example 7: $X$ spreads a rumor that the house of her divorced husband, $Y$, is condemned. Although specific im content, the lack of a discernible profit motivation and the failure to einploy an advertiseinent form allows $X$ 's publication to be classified as noncommercial speech.

Example 8: $Y$ loses an opportunity to sell Blackacre because $X$ told the potential buyer that $Y$ 's title was clouded. In fact, $Y$ 's title to Blackacre is clear although his title to the adjoming property is clouded. Published orally without discernible profit motive, $X$ 's speech is noncommercial.

Having cliaracterized the speech as commercial or noncommercial, the analysis proceeds as follows.

\section{If the Disparaging Speech Is Commercial, Constitutional Privi-} lege Is Inapplicable. Recently, some courts have dismissed coinmercial speech arguments in disparagement actions by noting that commercial speech is protected by the first amendinent. ${ }^{93}$ This position drastically oversimplifies the commercial speech doctrine. In fact, ouly truthful, nonmisleading commercial speech is protected by the first amendment. The tort of disparagement itself, however, limits recovery to damage caused ouly by false speech. ${ }^{94}$ Thus, commercial speecli that is slown to be disparaging-and therefore false-lias no first ainendment

92. See supra note 86 and accompanying text.

93. See, e.g., Blatty v. New York Times Co., 42 Cal. 3d 1033, 1047 n.3, 728 P.2d 1177, 1186 n.3, 232 Cal. Rptr. 542, 551 n.3 (1986) (en banc) ("Blatty argues in effect that the First Amendment is inapplicable ... on the ground that in that context the list constitutes 'commercial speech.' The argument is unpersuasive. . . . In any event, Blatty's major premise is false: commercial speech is not excluded from First Amendment protections.").

94. See infra notes 123-34 and accompanying text. That the tort of disparagement can only punish false speech is crucial to the analysis in this note and has been overlooked by other commen. tators. Thus, one commentator concluded:

In applying the commercial speech doctrine to corporate defamation and product disparagement cases, the inotive-based test suggests that a fundamental distinction should be drawn between speakers who are competitors and those who are non-competitors. If analysis is based on the value to society of particular information, however, a distinction between competitor and non-competitor speech is irrelevant. A competitor acting from pure self-interest and a third party disclosing the results of a disinterested survey may offer identical product information, and yet only the former may be subject to restraint.

Note, supra note 22 , at 977 . This writer's analysis assumes that the speech is valuable. In fact, since neither the competitor nor the noncompetitor is publishing true, socially useful information, favoring the disinterested party creates no problems. 
protection. ${ }^{95}$

Indeed, the rationales that support protection of speech do not apply to disparaging commercial speech. In the constitutional privilege decisions discussed earlier, the Supreme Court emphasized the high value of the speech at issue and its susceptibility to being chilled. ${ }^{96}$ These same rationales, lowever, do not support application of constitutional privilege to disparaging commercial speech: commercial speecl1 is neither of ligh value nor in danger of being clilled. ${ }^{97}$ Thus, whether the seller is a "public" or "private" figure is irrelevant when the disparagement is commercial in nature-in either case New York Times protection is unnecessary and inapplicable.

3. If the Disparaging Speech is Noncommercial, a New York Times Form of Analysis Should Be Applied. As the New York Times analysis lias developed over the years, the concepts of constitutional privilege and reputation have become intertwined. Constitutional privilege, lowever, is not so much concerned witl reputation-after all, the doctrine hinders recovery for defamatory publications-as it is with protectimg the speech of the publisher. Earlier, this note recognized that the torts of defamation and disparagement remedy injuries to distinct interests. ${ }^{98}$ This distinction between the interests protected should not, lowever, obscure the fact tliat in both torts the injury is caused by false speech. Thus, the question is not whether constitutional privilege should apply to speech concerning property-constitutional privilege adlieres to the speech itself, not its subject-but rather wliat form constitutional privilege slould take when the speech is disparaging ratlier than defamatory.

The application of constitutional privilege to noncommercial disparaging speecli appears simple at first glance because tlie elements of disparagement and defamation are roughly parallel. The first step in the

95. See supra notes 70-72 and accompanying text. See also Dairy Stores, Inc. v. Sentinel Publishing Co., 191 N.J. Super. 202, 216 n.4, 465 A.2d 953, 960 n.4 (Law Div. 1983) (noting that New York Times privilege might not be applied in the context of commercial disparagement), aff'd, 198 N.J. Super. 19, 486 A.2d 344 (App. Div. 1985), aff'd, 104 N.J. 125, 516 A.2d 220 (1986); Emory Comment, supra note 73, at 766; Valparaiso Note, supra note 73, at 857 .

One commentator argued that "[t] he constitutionalization of product disparagement is likely to reduce substantially the number of product disparagement actions brought by the manufacturers or sellers of disparaged products, since the burden of overcoming the constitutional privilege will probably deter plaintiffs from entering into costly litigation." Note, Bose Corporation v. Consumers Union of the United States, Inc.: Extending the New York Times Privilege to Product Disparagement, 44 U. PITT. L. REv. 1039, 105\$ (1983). This unfortunate result would discourage private action against false commercial speech, imposing a greater burden on governmental bodies that regulate deception in the marketplace.

96. See supra notes $46-47$ and accompanying text.

97. See supra notes 61-69 and accompanying text.

98. See supra notes $23-32$ and accompanying text. 
New York Times analysis, lowever, requires a distinction between public and private figures. How should a similar distinction be made between disparaged property interests?

The courts have taken two approaches in applying constitutional privilege to derogatory speech concerning a business entity or a property interest. ${ }^{99}$ One group of courts has examined the extent of advertising to determine whether the property or its owner or purveyor is a "public figure." 100 A second group tries to determine whether the case involves a "public controversy" and only then applies constitutional privilege. ${ }^{101}$

Botli tests focus on an important type of "public" property. A company that engages in a national advertising campaign thrusts its product into the spotlight and cannot complain when defects in the product are subsequently observed. ${ }^{102}$ Such a company is also likely to have access to the media to correct any misinformation concerning the product. ${ }^{103}$

Example 9: $X$, a consumer magazime, falsely reports that a nationally promoted product of $Y$ Corporation is unsafe for household use. In a subsequent action for disparagement, $X$ may claim constitutional privilege.

Similarly, soine property that is never advertised may draw the public's attention as a result of its owner's actions or status. ${ }^{104}$

Example 10: $X$, a newspaper, falsely reports that $Y$, a nominee to the Supreme Court, lives in a home that has been condemned. In a subsequent action by $Y$ against $X$ for disparagement, $X$ may claim constitutional privilege.

99. Both disparagement and corporate defamation cases are helpful in this analysis. Cases determining the status of the corporate defamation or disparagement plaintiff are analyzed in Emory Comment, supra note 73, at 774-87, and Valparaiso Note, supra note 73, at 862-74.

100. See, e.g., Bose Corp. v. Consumers Union of U.S., Inc., 508 F. Supp. 1249, 1271-74 (D. Mass. 1981) (product disparagement), rev'd, 692 F.2d 189 (1st Cir. 1982), aff'd, 466 U.S. 485 (1984); Steaks Unlimited, Inc. v. Deaner, 623 F.2d 264, 280 (3d Cir. 1980) (corporate defamation).

101. See General Prods. Co. v. Meredith Corp., 526 F. Supp. 546, 552 (E.D. Va. 1981) (finding no evidence of a public controversy surrounding the plaintiff's product sufficient to invoke the malice rule of New York Times); Martin Marietta Corp. v. Evening Star Newspaper Co., 417 F. Supp. 947, 956 (D.D.C. 1976) (libel action for report of defense contractor improprieties); $c f$. Time, Inc. v. Hill, 385 U.S. 374, 387-88 (1967) (constitutional protection afforded publication involving public interest). See generally Fetzer, The Corporate Defamation Plaintiff as First Amendment "Public Figure": Nailing the Jellyfish, 68 Iowa L. REV. 35, 73-86 (1982); Comment, A Criticism of the Gertz Public Figure/Private Figure Test in the Context of the Corporate Defamation Plaintiff, 18 SAN D1EGO L. REV. 721, 729-42 (1981); Note, supra note 22, at 1046-50.

102. Cf. Gertz v. Robert Welch, Inc., 418 U.S. 323, 345 (Some "public figures have thrust themselves to the forefront of particular public controversies in order to influence the resolution of the issues involved. ... [T] [Tey invite attention and comment.").

103. See Prosser \& KeEton, supra note $13, \S 113$.

104. See, e.g., Racial Restriction Found in 2nd Deed, Washington Post, Aug. 1, 1986, at A1, col. 6 (reporting on racially restrictive covenants in deed to then Associate Justice Rehnquist's property in connection with his nomination to the position of Chief Justice). 
Example 11: $X$, a newspaper, falsely reports that $Y$, a private citizen, lives in a home that has been condemned. $X$ may not claim constitutional privilege in a subsequent disparagement suit.

Of course, most cases will present more difficult examples, as neither the "public figure" nor the "public question" test provides a bright-line division. ${ }^{105}$ The analysis required, however, is probably no more onerous than that made in defamation actions.

\section{Afterword: A Holistic Look at Disparaging Speech.}

One of the problems in the jurisprudence of the first amendment is that the analysis depends on the category into which the speech falls. ${ }^{106}$ The preceding section adhered to that categorization of commercial and "New York Times" speecl in its analysis. Nevertheless, although established precedent makes this approach necessary in resolving litigation, it is beneficial to look at the resulting first amendment structure as a whole.

This note suggests that the umiverse of disparaging speech is divided into two categories: false ${ }^{107}$ commercial speech and false noncommercial speech. In turu, eacli of these categories is divided into two parts: speech on a public issue and speech not on a public issue.

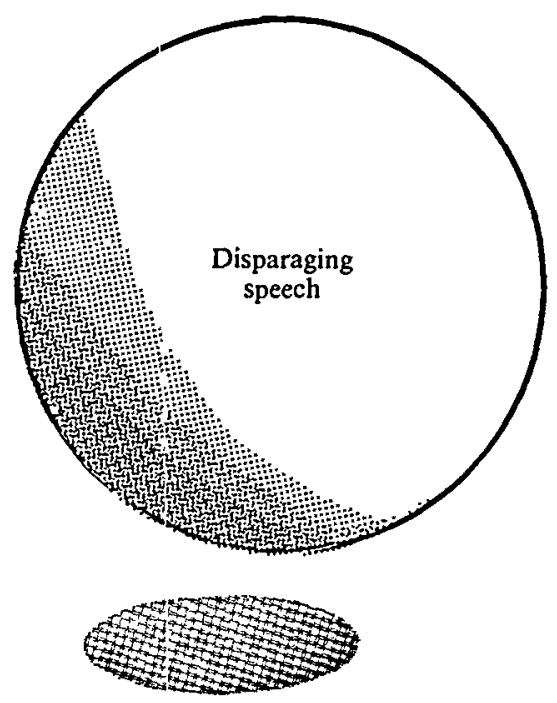

105. Cf. Fetzer, supra note 101, at 83 ("None of the theories proposed in recent decisions ... posits a workable, coherent approach to the corporate defamation plaintiff.").

106. See generally 3 R. RotundA, J. NowaK \& J. YounG, supra note 51, at § 20.1.

107. False because, as this note emphasizes, disparaging speech is always false. 

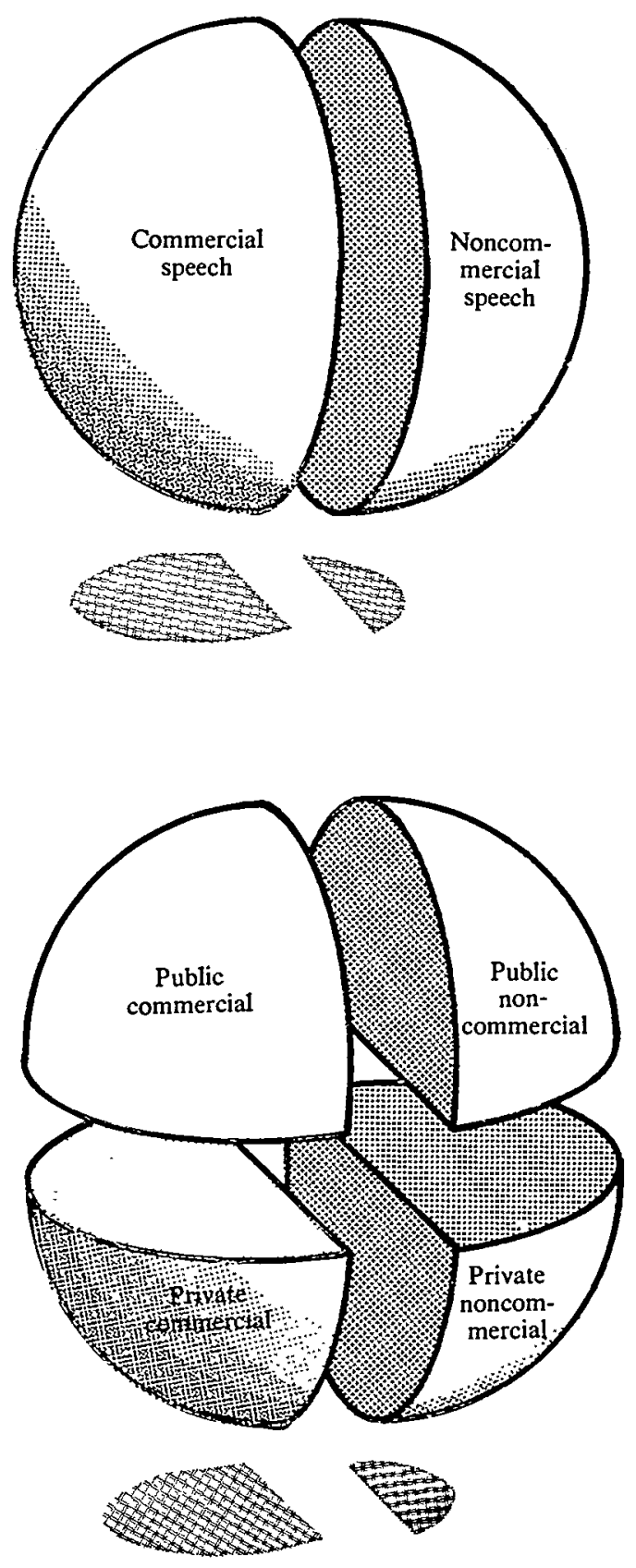
The decision of the Supreme Court in Virginia Pharmacy held that commercial speech, while worthy of limited protection if truthful, is outside the scope of first amendment protection if untruthful. ${ }^{108}$ In Central Hudson, the Court dealt with commercial speech on a public issue, and found that it too is worthy only of limited protection-and by imphcation, no protection if the speech is found to be false. ${ }^{109}$ Thus all commercial disparaging speecli, whether or not it concerns a public issue, is outside the scope of the first amendment and is not afforded the heightened protection given by constitutional privilege.

Similarly, the decision of the Supreme Court in New York Times defines a type of speech that is of high value because of its contribution to public debate; such speech, therefore, is worthy of first amendment protection even if false. ${ }^{110}$ Noncommercial disparaging speech can likewise address questions of public concern; thus, it is proper to apply a constitutional privilege to such speech. Mucli noncommercial disparaging speech, however, will not address a public issue. In such cases, the full protection of the first amendment is not warranted and only the most marginal constitutional protections are given. ${ }^{111}$

The process explained above provides a framework by which one may scrutinize the tort of disparagement as a whole under a constitutional light. It also allows one to determine what effect the first amendment should have on individual elements of the tort.

\section{The Effect of the First Amendment on the Elements OF THE TORT OF DISPARAGEMENT}

As in defamation, the first amendment has had its greatest impact on the elements of falsity, intent and damage within the tort of disparagement. Nevertheless, a discussion of the other elements of the disparagement action is first necessary to establish a complete view of the action.

\section{A. Elements Not Affected by the First Amendment: Publication, Disparagement and Privilege.}

Publication of a disparagement is defined as "its communication intentionally or by a negligent act to someone other than the person whose interest is affected." 112 Virtually any form of communication, mcluding the placing of a lien, is encompassed by this defintion. ${ }^{113}$ The laws defin-

108. See supra notes $59-72$ and accompanying text.

109. See supra notes 88-91 and accompanying text.

110. See supra notes $46-56$ and accompanying text.

111. See supra notes $57-58$ and accompanying text.

112. Restatement (SECOND) OF TORTS $\S 630$ (1976).

113. Id. $\S 630$ comment b. 
ing publication for defamatory and disparaging speecl have effectively merged, ${ }^{114}$ and currently present no first amendment issues.

In disparagement, as in libel and slander, the coinmunicated language must be capable of derogatory meaning. ${ }^{115}$ Language that does not deprecate an interest of the plaintiff is not actionable. The protected interests have slowly expanded in the course of the tort's development and now include any type of property. ${ }^{116}$ Althougl deprecation of the services of another was traditionally treated as defanation, ${ }^{117}$ some courts now treat the action as one of disparagement.118 This approach reflects both the expansion of the economic rights now redressed by the more general action for injurious falsehood ${ }^{119}$ and the original commercial emphasis of the tort of disparagenient.

The privileges available in disparagenient actions largely parallel those available in the tort of defamation. ${ }^{120}$ Two privileges, however, are unique to disparagement. First, a "rival claimant is conditionally privileged to disparage another's property in land, chattels or intangible things by an assertion of an inconsistent legally protected interest in him-

114. Id. $\S 630$ comment a.

115. Id. § 629.

116. Professors Odgers and Ritson stated:

The property may be either real or personal, corporeal or incorporeal; and the plaintiff's interest therein inay be either in possession or reversion. It need not be even a vested interest, so long as it is anything that is saleable or that has a market value. The title to the property may be legal or equitable. The word "property" includes a patent right, copyright, the right to use a trade mark or a trade name.

W.B. Odgers \& R. RITSON, A Digest OF THE LAW OF Libel AND SLANDER AND OF Actions ON THE CASE FOR Words CAUSING Damage 70 (6th ed. 1929).

117. Although the definition of property within the tort of disparagennent is very broad, see supra note 116, it probably did not traditionally encompass a service. Thus, the provider of a service is more likely defamed than disparaged. See, e.g., RESTATEMENT (SECOND) OF TORTS $§ 573$ comment c (1976) ("When peculiar skill or ability is necessary, an imputation that attributes a lack of skill or ability [is defamatory].").

118. See, eg., Crinkley v. Dow Jones \& Co., 67 Ill. App. 3d 869, 876, 385 N.E.2d 714, 719 (1979) ("[T] he common law tort of commercial disparagement . . . has consistently been applied to statements which disparage the quality of one's goods or services."); Ruder \& Finn Inc. v. Seaboard Sur. Co., 52 N.Y.2d 663, 670-71, 422 N.E.2d 518, 522, 439 N.Y.S.2d 858, 862 (1981) ("Where .. . the statement is confined to denigrating the quality of the busimess' goods or services, it could support an action for disparagement...."). Similarly, actions for the defamation of business reputation could follow the analytic structure of disparagement.

119. Prosser explains:

Injurious falsehood, or disparagement, then, may consist of the publication of matter derogatory to the plaintiff's title to his property, or its quality, or to his business in general, or even to some element of his personal affairs, of a kind calculated to prevent others from dealing with him, or otherwise to interfere with his relations with others to his disadvantage.

Prosser \& KeEton, supra note $13, \S 128$.

120. See RESTATEMENT (SECOND) OF TORTS $\$ \S 635,646 \mathrm{~A}$ (1976) (stating that the absolute and conditional privileges available in defamation apply equally to disparagement). 
self."121 Thus, $X$ is privileged to disparage $Y$ 's ownership of Blackacre if $X$ does so in good faith, believing himself to be the owner, despite the fact that such belief is unreasonable or incorrect. This privilege for rival claimants ensures that people will not be deterred from asserting their commercial rights by a fear of subsequent civil action-in effect, it prevents a "chilling" of economic speech. A second privilege unique to disparagement allows a seller to tout his products as superior to those of a competitor-even if the seller knows that they are not. ${ }^{122}$ This privilege to "puff" one's goods also ensures that commercial speech is given some "breathing space."

\section{B. The Effect of the First Amendment on the Element of Falsity.}

Before New York Times forced courts to consider defamation in light of the first amendment, the falsity of a defamatory publication was presumed, leaving the defendant with the burden of proving an affirmative defense of truth. ${ }^{123}$ After New York Times, the constitutionality of a presumption of falsity became questionable when a public figure was involved, ${ }^{124}$ and the Supreme Court recently has explicitly held sucli a presumption unconstitutional even as applied to private figures so long as a matter of public concern is involved. ${ }^{125}$ A defamatory publication that does not concern either a public figure or public issue, lowever, is still generally presumed false. ${ }^{126}$

In marked contrast to the treatment given falsity in a defamation action, the common law has always required a plaintiff to prove that a disparaging publication was false.127 This allocation of the burden of proof protects all publishers-commercial and noncommercial, private and public. Thus, with regard to falsity, disparagement provides greater substantive protection to the speaker than does defamation, and therefore is aligned with the New York Times analysis.

The requirement of proof of falsity in a disparagement action, how-

121. Id. at $\S 647$. This privilege is, of course, limited to the context of slander of title.

122. Restatement (SECOND) OF TORTS $\$ 649$ (1976) (A competitor is "conditionally privileged to make an unduly favorable comparison ... if the comparison does not contain false assertions of specific unfavorable facts regarding the rival competitor's things.").

123. See Prosser \& KeEton, supra note 13, § 113, at 804.

124. See id. at 805-06.

125. Philadelphia Newspapers, Inc. v. Hepps, 475 U.S. 767, 776 (1986).

126. See Prosser \& KeETon, supra note $13, \S 113$, at 805 .

127. See System Operations, Inc. v. Scientific Games Dev. Corp., 555 F.2d 1131, 1142 (3d Cir. 1977) (following "the apparently unanimous view of other jurisdictions that the plaintiff in a product disparagement action must bear the burden of proving the falsity of the disparaging communications"); see also Restatement (SECOND) OF TORTS § 651(1)(c) (1976); Prosser \& KeETON, supra note $13, \S 128$. 
ever, has become problematic. As in defamation actions, ${ }^{128}$ a plaintiff in a disparagement action must show the falsehood to be substantial, going to the gist of the publication. ${ }^{29}$ Because the tort of disparagenent has always provided a greater degree of protection to a publisher than did defamation, the policies behind this rule should be considered even stronger in disparagement actions. A recent district court decision, however, appears to have departed from this standard.

In Bose Corp. v. Consumers Union of United States, Inc., 130 the United States District Court for the District of Massachusetts considered a review published by Consumer Reports which stated that the sound of a Bose speaker moved "about the room." In fact, evidence showed that the sound moved "along the walls" of the room. ${ }^{131}$ The district court held that the difference between the two phrases was sufficient to establish that the article was false. ${ }^{132}$ In this particular proceeding any constriction of first amendment breathing space by the trial court's strict interpretation of falsity was resolved by proper application of the actual malice standard by the appellate court. ${ }^{133}$ Nonetheless, even in the context of commercial speech, falsity should not be so strictly construed that no latitude for figurative expression remains. ${ }^{134}$ Bose is counter to the level of falsity suggested by constitutional concerns and slould not be followed by other courts.

\section{The Relationship Between the First Amendment and the Element of Intent.}

The common law has never fully resolved the level of intent neces-

128. See Restatement (SECOND) OF TORTS $§$ 581A comment $f$ (1976) ("It is not necessary to establish the literal truth of the precise statement made. Slight inaccuracies of expression are immaterial provided that the defamatory charge is true in substancc.").

129. See Gee v. Pima County, 126 Ariz. 116, 117, 612 P.2d 1079, 1080 (Ariz. Ct. App. 1985) (Howard, J., specially concurring) (looking past a technical falsity created by artful pleading); Bothmann v. Harrington, 458 So. 2d 1163, 1168 (Fla. Dist. Ct. App. 1984) (substantive falsity necessary to establish disparagement); Matheson v. Harris, 98 Idaho 758, 761, 572 P.2d 861, 864 (1977) (technical mistakes not falsehoods for the purpose of disparagement).

130. 508 F. Supp. 1249 (D. Mass. 1981), rev'd, 629 F.2d 1249 (1st Cir. 1982), aff'd, 466 U.S. 485 (1984).

131. Id. at $1267-68$.

132. Id. at 1268 .

133. Bose Corp. v. Consumers Umion of United States, Inc., 692 F.2d 189, 197 (1st Cir. 1982) (" $\mathrm{CU}$ was guilty of using imprecise language in the article-perhaps resulting from an attempt to produce a readable article for its mass audience. Certainly this does not support an inference of actual mahice."), rev'g 508 F. Supp. 1249 (1980), aff'd, 466 U.S. 485 (1984).

134. Another element of the tort underscores the need for material falsity: harm must be substantially caused by the false publication. If the falsehood is not significant, the plaintiff will not be able to prove special damages. See infra notes 153-74 and accompanying text. 
sary to prove an action for disparagement. ${ }^{135}$ Properly, the action hinges on at least two types of intent: intent to injure and intent to falsify. ${ }^{136}$ American common law decisions, however, have used a variety of intent formulations. ${ }^{137}$ Some courts have always required that the plaintiff prove a level of scienter similar to constitutional malice. ${ }^{138}$ Other decisions imply that proof of ill will ${ }^{139}$ or intent to injure ${ }^{140}$ eliminates the need to determine whether the publisher was aware of falsity. Actions for slander of title to realty are often even more generous to the plaintiff. ${ }^{141}$ Suits for injurious falsehood, however, have uniformly required a high standard of malice. ${ }^{142}$ Evaluating these cases, one commentator has concluded: "The number of cases which have turned on what the plamtiff must allege and prove to show intent is so small and the holdings on the subject so fragmentary that future courts may have little trouble distinguishing precedents away in order to arrive at new formulae."143

This confusion is not unsolvable: the same analysis that was used to apply the first amendment to disparaging speech also provides a viable framework for determining what level of intent should be shown in a

135. See Black \& Yates, Inc. v. Mahogany Ass'n, 129 F.2d 227, 229-30 (3d Cir.) (“'Even a]fter the courts crystallized the tort certain elements remained uncertain. There was not entire agreement on two points, the always technical and confusing conception of malice and the matter of special damage.") cert. denied, 317 U.S. 672 (1942); Comment, The Law of Commercial Disparagement: Business Defamation's Impotent Ally, 63 YALE L.J. 65, 78-79 (1953).

136. See RESTATEMENT (SECOND) OF TORTS $§ 623$ A (1976). The position of the second Restatement departs greatly from that of the first Restatement, which suggested a strict liability standard similar to that in common law defamation. See RESTATEMENT OF TORTS $\S 625$ (1938); Prosser, supra note 21 , at $430-31$.

137. An excellent discussion of the intent level required by American courts and suggested by commentators is found in 2 F. HARPER, F. JAMES \& O. GRAY, THE LAW OF TORTS $\$ 6.1 \mathrm{~A}$ (2d ed. 1986). See also Prosser, supra note 21, at 428-39; Comment, supra note 135, at 78-84.

138. See Restatement (SeCOND) OF ToRTs § 623A comment d (1976) ("A principal basis for liability for injurious falsehood has been that the publisher knew that the statement was false or that he did not have the basis of knowledge or belief professed by his assertion. This is the same test as that for scienter in the tort of deceit.").

139. See id. $\S 623 \mathrm{~A}$ comment d "At common law, the publisher of an injurious falsehood was also held subject to liability, ... if he was motivated by ill will toward the other (malice, in the factual sense) ...."); Comment, supra note 135, at 78-79.

140. See Restatement (SECOND) OF TORTS § 623A comment d (1976) ("At common law, the publisher of an injurious falsehood was also held subject to liability ... if he intended to interfere with the interests of the other in an unprivileged manner (intent to harm)."). Conversely, intent to injure has been presumed when the plaintiff has proven an intent to falsify. See Comment, supra note 135 , at 78 n.75.

141. Comment, supra note 135 , at $86 \mathrm{n} .113$ ("In slander of title cases, a statement made without an intent to injure is generally actionable.").

142. Id. at $78 \mathrm{n} .73$.

143. Id. at 79 n.75. A more detailed analysis of the level of intent required at common law is beyond the scope of this note. The necessary level of intent varies from negligence in some jurisdictions to scienter in others. Generally, the common law requirement of intent is less onerous than that required by New York Times. 
disparagement action. As with the application of the first amendment, the first step is to recognize that there are two groups of disparaging speech: noncommercial speech-which is further divided into speech on matters of pubhic concern and speech on private matters-and commercial speech.

The level of intent required to recover for disparaging, noncommercial speech concerning property in the public eye is the least difficult to determine (and the most difficult for the plamtiff to prove). The same arguments that mandate application of constitutional privilege to defamation also dictate that a plaintiff complaining of noncommercial disparaging speech that concerns a public figure or issue satisfy a standard of actual malice for intent to falsify, and negligence for intent to injure. ${ }^{144}$

Example 12: $X$, a newspaper, states that $Y$ 's goods, which are nationally advertised to be of premium quality, are shoddy. $Y$ must prove actual makice with regard to falsity and negligence with regard to mjury.

When considering noncommercial speech that does not concern a public issue, courts should continue to apply the standards for disparagement that have developed through the common law. ${ }^{145}$ These common law formulations tend to result im recovery for a level of intent which ranges from negligence to scienter. ${ }^{146}$ In this area, the only constitutional restraint is that the plaintiff must at least show neghigence with regard to both intent to falsify and intent to injure. ${ }^{147}$

Example 13: $X$, a landowner, tells $Z$ that the title to $Y$ 's farm is not clear. $Y$ must satisfy the intent level required in the local jurisdiction, but that level inust at least require neghigence with regard to both falsity and injury.

144. See RESTATEMENT (SECOND) OF TORTS $\$ 623$ A (1976) (listing actual malice as an element of injurious falsehood and explaining exceptions concerning the sufficiency of lesser degrees of intent).

145. See, e.g., General Prods. Co. v. Meredith Corp., 526 F. Supp. 546, 553-54 (E.D. Va. 1981) (common law intent applied when defendant a private figure).

146. See supra notes 135-44 and accompanying text. The distinctions between the various forms of disparagement would be preserved. Consequently, the plaintiff in a case of injurious falsehood might have a greater burden with regard to intent than would a plaintiff in a slander of title action.

147. See Gertz v. Robert Welch, Inc., 418 U.S. 323, 347 (1974). A system allowing recovery when a "reasonable man would have foreseen that his statement would disparage" and "should have ascertained that his statement was false" is in fact suggested in Comment, supra note 135, at 84 . The author there concluded:

Since the plaintiff would still have to prove only what the defendant should have known, recovery would be a practical possibility. On the other hand, freeing the defendent from liability unless he was negligent in failing to realize that his statement was false gives discussion sufficient latitude. Intelligent commentary would be preserved; anyone who had good reason to believe his statement was true would escape liability. Only irresponsible statements, of relatively little social value, would be grounds for suit.

Id. at 84 . 
As discussed above, a large amount of speech falls under the rubric of commercial disparaging speech. The common law intent formulation of the local jurisdiction could also be properly apphed to commercial disparagement, except that no minimum negligence requirement would appear to be mandated. Alternatively, the same rivalry that establishes the speech's commercial nature ${ }^{148}$ could also determine the level of intent required. In a commercial setting, intent to injure is almost inherent, because the primcipal inotivation of commercial speech is to create profit at the expense of the coinpetition. Thus, imtent to injure could be presumed, subject to rebuttal. ${ }^{149}$ With respect to intent to falsify, a negligence standard would be appropriate because false commercial speech is constitutionally unprotected. ${ }^{150}$

Example 14: $X$, a manufacturer of widgets, places an advertisement which states that the wiclgets of $Y$ are of low quality. $Y$ brings an action for disparagement of quality. The economic competition between $X$ and $Y$ establishes the speech as commercial. $Y$ need only show that $X$ was negligent with regard to falsity, and intent to injure is presumed.

\section{First Amendment Limitations on the Element of Damages and Equitable Relief.}

1. Special Damages. Recovery for disparagement is limited to "special," i.e., "actual" danages, ${ }^{151}$ which the plaintiff is required to prove. ${ }^{152}$ The lost sale is the basic measure of special damages withm the tort of disparagement, and the action should properly fail absent such a showing. ${ }^{153}$ Extra damages can be added to this base figure to rehabilitate fully the plaintiff-courts have awarded interest on the loss, ${ }^{154}$ main-

148. See supra notes $83-86$ and accompanying text.

149. See Smith, supra note 83, at 19-21 (malice should be presumed where the parties are competitors). Interestingly, another commentator has reached the opposite conclusion:

The mere fact that the plaintiff and the defendant are rivals in the same line of business is by itself no evidence of malice; indeed, it rather tends to negative malice, as it renders it probable that the words were published with the object of promoting the defendant's own trade and not of injuring the plaintiff.

W.B. ODGERS \& R. RITSON, supra note 116, at 80 . This reasoning would, in effect, further extend a publisher's right to "puff" his goods, see supra note 122 and accompanying text, while making false and injurious statements more difficult to remedy; it is therefore unpersuasive.

150. See supra notes $70-72$ and aceompanying text.

151. See, e.g., Restatement (SeCOND) OF TORTS $§ 633$ (1976); Prosser \& Keeton, supra note $13, \S 128$.

152. See, e.g., Restatement (SECOND) OF TORTS $\$ 651(1)(\mathrm{h})$ (1976) ("pecuniary loss"); ProsSER \& KEETON, supra note $13, \S 128$.

153. E.g., Dent v. Balch, 213 Ala. 311, 312, 104 So. 651, 652 (1925).

154. See, e.g., id. at 312, 104 So. at 652; Walker v. Ruggles, 540 S.W.2d 470, 476 (Tex. Civ. App. 1976); Olsen v. Kidman, 120 Utah 443, 449, 235 P.2d 510, 513 (1951). 
tenance costs, ${ }^{155}$ increased costs arising from delay, ${ }^{156}$ and protective measures. ${ }^{157}$ The cost of advertising necessary to rectify the disparagement is also properly awarded. ${ }^{158}$ Attorney fees and court costs inay also be awarded for legal action required to rehabilitate a slandered title, ${ }^{159}$ but not for the disparagement suit itself. 160

Although a loss is often easily established, proving that the loss was the result of the disparageinent is frequently difficult. Early cases took a strict view of causation and required the plaintiff to produce custonners who had been deterred from dealing with the plaintiff by the publication of the disparageinent. ${ }^{161}$ The modern approach is more flexible, as Bose Corp. v. Consumers Union of U.S., Inc. ${ }^{162}$ demonstrates.

As explained earher, the Bose court found a stateinent published by Consumers Umion in its magazine, Consumer Reports, to be false. ${ }^{163}$ Lost sales were quantified by a drop in the rate of sales increases over the corresponding months of the previous year. The court attributed seventy-five percent of the loss to the false stateinent, and twenty-flve per-

155. See, e.g., Walker, 540 S.W.2d at 476.

156. See id.

157. See, e.g., Cromarty v. Prentice-Hall, Inc., 72 A.D.2d 782, 783, 421 N.Y.S.2d 603, 604-05 (1979) (recognizing that claim might be made by owners of house depicted in the book The Amityville Horror-A True Story for refuse collection, guard services, and fence construction necessitated by curiosity-seekers).

158. See, e.g., Charles Atlas, Ltd. v. Time-Life Books, Inc., 570 F. Supp. 150, 155 (S.D.N.Y 1983).

159. See Glass v. Gulf Oil Corp., 12 Cal. App. 3d 412, 437-38, 96 Cal. Rptr. 902, 919-20 (1970); Chesebro v. Powers, 78 Mich. 472, 478-79, 44 N.W. 290, 291-92 (1889); Summa Corp. v. Greenspun, 98 Nev. 528, 532, 655 P.2d 513, 515 (1982); Walker, 540 S.W.2d at 476; see also RESTATEMENT (SECOND) OF TORTS § 633(1)(b) (1976) (measure of damages includes "the expense of measures reasonably necessary to counteract the publication, including litigation to renove the doubt cast upon vendibihty or value by disparagement"). But see Hubbard v. Scott, 85 Or. 1, 13-14, 166 P. 33, 36-37 (1917) (not allowing award of extra fees).

160. See City of Shreveport v. Kahn, 194 La. 55, 67, 193 So. 461, 465 (1939); American Nat'l Bank \& Trust Co. v. First Wis. Mortgage Trust, 577 S.W.2d 312, 319-20 (Tex. Civ. App. 1979); McGuinness v. Hargiss, 56 Wash. 162, 164-65, 105 P. 233, 234 (1909). But see Johnson v. Murray, 201 Mont. 495, 509, 656 P.2d 170, 177 (1982) (allowing award of trial costs in particularly egregious case).

161. E.g., Berryınan v. Sinclair Prairie Oil, 164 F.2d 734, 737 (10th Cir. 1947); Stevenson v. Love, 106 F. 466, 468 (C.C.D.N.J. 1901); Carroll v. Warner Bros. Pictures, Inc., 20 F. Supp. 405, 408 (S.D.N.Y. 1937); Zimmerman v. Hinderlider, 105 Colo. 340, 348, 97 P.2d 443, 447 (1939); Wilson v. Dubois, 35 Minn. 471, 473, 29 N.W. 68,69 (1886); Briggs v. Coykendall, 57 N.D. 785, 792-93, 224 N.W. 202, 206 (1929); Hubbard v. Scott, 85 Or. 1, 12-13, 166 P. 33, 36 (1917); Shell Oil Co. v. Howth, 138 Tex. 357, 366-67, 159 S.W.2d 483, 490 (1942); Barquin v. Hall Oil Co., 28 Wyo. 164, 171-72, 201 P. 352, 354-55 (1921).

162. 529 F. Supp. 357 (D. Mass. 1981), rev'd, 692 F.2d 189 (1st Cir. 1982), aff'd, 466 U.S. 485 (1984). This, the second of the two Bose trial court decisions, dealt solely with special danages. The appellate court considered both trial court decisions, but reversed before and specifically without reaching the issue of special damages. $692 \mathrm{~F} .2 \mathrm{~d}$ at 197.

163. 529 F. Supp. at 359-60. 
cent to other unfavorable statements "not proved to be false." 164 The court rejected Consumers Union's argument that the plaintiff had not proven causation: "The defendant may not unfairly place the burden on the plaintiff to prove that no other factor was imvolved or to apportion with mathematical certamty and precision the dollar amount of the imjury it suffered from each particular statement."165 Bose Corporation was awarded over $\$ 100,000$ in dainages. ${ }^{166}$

The opmion of the district court in Bose presents a detailed but unconvincing discussion of causation. In a disparagement action, the plamtiff must prove that the publication was at least a substantial factor in bringing about the loss. ${ }^{167}$ The Bose court's determination of causation was questionable: inuch of the publication was both true and uncomplimentary and the truthful uncomplimentary statenients also could have brought about the lost sales. The tort of disparagement of course, does not allow recovery based upon such truthful uncomplimentary statements. ${ }^{168}$ Allowing the plaintiff to rely on the loss of an unidentified customer base made causation even nrore tenuous. ${ }^{169}$ Altlougl the "substantial factor" and the "unidentified patron" analyses may work well independently, their use in conıbination produces only speculative proof of causation.

The district court that decided Bose was also liberal as to the calculation of lost sales. The court found that sales dropped from 155 percent to 120 percent of the previous year's sales. ${ }^{170}$ Such a finding says nothing

164. Id. at 364 .

165. Id. at 362 .

166. Id. at 365 .

167. RESTATEMENT (SECOND) OF TORTS $§$ 632(a) (1976). The second Restatement bifurcates the damages analysis into a "substantial factor" test for causation and a "direct and immediate" test for quantification of loss. See id. $\S \S 632-633$. Many courts, however, seem to ignore the bifurcated analysis, instead requiring that loss re:ult "directly and immediately from the falsehood's effect on the conduct of third persons." Bothmann v. Harrington, 458 So. 2d 1163, 1170'(Fla. Dist. Ct. App. 1984) (citing RESTATEMENT (SECOND) OF TORTS $\S 633$ (1976)). See also Glass v. Gulf Oil Corp., 12 Cal. App. 3d 412, 425, 96 Cal. Rptr. 902, 910 (1970); Walker v. Ruggles, 540 S.W.2d 470, 474-76 (Tex. Civ. App. 1976).

168. The common law rule for such situations was much harsher than the "substantial factor" standard adopted by the second Restatement. See Brook v. Rawl, 4 Exch. Rep. 521, 524, 154 Eng. Rep. 1320, 1321 (1849) (opinion of Parke, B.) ("If some portions of the statement which a person makes are bonâ fide, but others are rnalâ fide and occasion injury to another, the injured party cannot recover damages, unless he can distinctly trace the damage as resulting frorn that part which is made malâ fide.").

169. The second Restatement, stating that the loss of unidentified customers is a question of fact that must be shown with "reasonable certainty," notes that evaluation of particular evidence was beyond the scope of the treatise. RESTATEMENT (SECOND) OF TORTS $\S 633$ cornment h (1976).

170. Bose, $529 \mathrm{~F}$. Supp, at 364 . Sales in the first four months of 1970 were $155 \%$ of sales for those months in the preceding year. During the last eight months of 1970 , after publication of the disparagement, sales were only $120 \%$ of sales for the last eight months of 1969 . Id. 
about whether sales actually dropped in volume after the publication of the disparagement. While a proven drop in sales is now accepted as evidence of loss, ${ }^{171}$ plaintiffs generally may not recover for a reduced increase in sales, as such allegations are considered speculative. ${ }^{172}$

Bose illustrates that there are inherent limits on recovery in a disparagement action. Even when these limits are stretched almost to the breaking point, as in Bose, the plaintiff cannot recover anything other than proven pecuniary loss. These limitations upon recovery stand in contrast to the action at common law for slander per se and hibel, in which damage was presumed. ${ }^{173}$ Even though New York Times inay now in some cases compel a defamation plaintiff to prove actual dainages, "actual damages" under New York Times allows a far greater recovery than does actual damages within the context of the tort of disparagement. ${ }^{174}$ Once again, the tort of disparagement is circumscribed in a fashion inore protective of free speech concerns than is the tort of defamation.

2. Punitive Damages. Courts have not readily awarded punitive damages in actions for disparagement. Those that have done so have generally required proof of "actual inalice"-that is, ill will, spite or a wanton disregard for the truth of the publication. ${ }^{175}$ Within the context of commercial disparaging speech, where constitutional privilege is inapphicable, this common law standard for punitive damages should continue to control: a manufacturer who proves his competitor acted out of

171. See, e.g., Erick Bowman Remedy Co. v. Jensen Salsbery Laboratories, 17 F.2d 255, 260 (8th Cir. 1926) (Special damages may be recovered "in exceptional cases, where there is a general loss of business."); Advanced Training Sys., Inc. v. Caswell Equip. Co., 352 N.W.2d 1, 7-8 (Minn. 1984) ("Where plaintiff cannot show loss of specific sales, the modern view allows plaintiff to prove a general decline of busiuess, so long as this is shown to be the result of defendant's disparaging statements and other possible causes are eliminated.").

172. See Advanced Training Sys., 352 N.W.2d at 8 (rejecting claim to special damages based on allegation that, abseut the disparagement, plaintiff's business would have been even more successful); Maytag Co. v. Meadows Mfg. Co., 45 F.2d 299, 302 (7th Cir. 1930) (same), cert. denied, 283 U.S. 843 (1931). But see Jumping Rainbow Ranch v. Conklin, 167 Mont. 367, 372-73, 538 P.2d 1027,1028 (1975) (allowing recovery of projected increase in profits).

173. See Prosser, Libel Per Quod, 46 VA. L. REV. 839, 842 (1960).

174. See Time, Inc. v. Firestone, 424 U.S. 448, 460-61 (1976) (awarding damages under New York Times for emotional distress); Gertz v. Robert Welch, Inc., 418 U.S. 323, 350 (1974) (defining actual damages to include nonpecuniary loss).

175. See Proctor v. Gissendaner, 579 F.2d 876, 882-83 (5th Cir. 1978); Forte v. Nolfi, 25 Cal. App. 3d 656, 687-88, 102 Cal. Rptr. 455, 476 (1972); Continental Dev. Corp. v. Duval Title \& Abstract Co., 356 So. 2d 925, 928 (Fla. Dist. Ct. App. 1978); Jumping Rainbow Ranch v. Conklin, 167 Mont. 367, 372-73, 538 P.2d 1027, 1030 (1975); Frega v. Northern N.J. Mortgage Ass'n, 51 N.J. Super. 331, 340-41, 143 A.2d 885, 890-91 (App. Div. 1958); Kendall v. Stone, 2 Sand. 269, 284 (N.Y. Super. Ct. 1848), rev'd on other grounds, 5 N.Y. 14 (1851); American Nat'1 Bank \& Trust Co. v. First Wis. Mortgage Trust, 577 S.W.2d 312, 317 (Tex. Civ. App. 1979); Walker v. Ruggles, 540 S.W.2d 470, 474 (Tex. Civ. App. 1976). 
ill will-purposefully falsifying disparaging information-should be allowed to recover punitive damages. Such a penalty is consistent with the Court's concern for truth in the marketplace. ${ }^{176}$

The proper standard for pumitive damages in cases involving noncommercial disparagement is unclear because first amendment guidelines concerning punitive damages are also unclear. In Gertz v. Robert Welch, Inc., 177 the Supreme Court announced that a showing of "actual malice" was necessary for a private imdividual to recover punitive damages in a defamation action. In Dun \& Bradstreet, Inc. v. Greenmoss Builders, Inc., 178 however, five justices agreed that the requirement of constitutional mahice for punitive damages did not apply when a private figure plaintiff and a matter of private concern were involved. ${ }^{179}$

In a noncommercial disparagement action in which no public figure or public matter is imvolved, the plamtiff should be required only to meet the common law requirement of scienter to recover punitive daniages. When constitutional privilege is applicable, however, the plaintiff must be required to prove "actual malice" just to recover special damages. ${ }^{180}$ Because there is no liigher level of intent, ${ }^{181}$ owners of property that is in the public eye will almost certainly be precluded from recovery of pumtive damages.

3. Equitable Relief. Although Britisli courts have long granted injunctions for disparagement, ${ }^{182}$ American courts traditionally have denied equitable relief. ${ }^{183}$ In Black \& Yates, Inc. v. Mahogany Associa-

176. See supra notes 59-72 and accompanying text.

177. 418 U.S. 323,349 (1974).

178. 472 U.S. 749 (1985).

179. Id. at 761 (plurality opinion); id. at 764 (Burger, C.J., concurring); id. at 774 (White, J., concurring).

180. See supra note 144 and accompanying text.

181. See 3 R. Rotunda, J. NowaK \& J. Young, supra note 51, § 20.33.

182. A few early cases seein to indicate that the common law allowed injunctive relief for disparagement. See James v. James, 13 L.R.-Eq. 421,425 (1872); Dixon v. Holden, 7 L.R.-Eq. 488, 492 (1869). In any case, the Judicature Act, 1873,36 \& 37 Vict. ch. 66 \& 25(8), and subsequent legislation have empowered British courts to enjoin both disparaging and defamatory speech. See 24 HALSBURY's LAWS OF ENGLAND para. 984 (4th ed. 1979); P. LEWIS, supra note 13, paras. 14721473; W. Kerr \& J. Paterson, A Treatise on the LaW and Practice of InJunctions 49596 (6th ed. 1927).

183. E.g., Heuer v. Basin Park Hotel \& Resort, 114 F. Supp. 604, 609 (W.D. Ark. 1953) ("[A] court will not enjoin the utterance of disparaging statements."); see also Boston Diatite Co. v. Florence Mfg. Co., 114 Mass. 69, 70 (1873); Marlin Fire Arms Co. v. Shields, 171 N.Y. 384, 391-96, 64 N.E. $163,165-67$ (1902).

Courts wishing to circumvent this analysis often found an independent basis for equitable relief. See H. MCClintock, HANDBOoK of 'THE PRINCIPLES OF EQuiry $§ 156$ (2d ed. 1948). Cf. Black \& Yates, Inc. v. Mahogany Ass'n, 129 F.2d 227, 231 (3d Cir. 1941) (granting injunctive relief "without 
tion, ${ }^{184}$ however, the United States Court of Appeals for the Third Circuit allowed injunctive relief for disparagement, ${ }^{185}$ recognizing that the American position barring injunctive rekef was based upon the fallacy that disparagenient is a form of defaniation. ${ }^{186}$ Commentators generally agree that injunctions can issue aganist disparaging speech. ${ }^{187}$

Defendants often have invoked the first amendnient's prohibition against prior restraints as a justification for denynig injunctive relief. ${ }^{188}$ In the context of conmercial disparagenent, this argument is of dubious validity. The Supreme Court has recognized that the prohibitions against prior restraints may be inapplicable to commercial speech. ${ }^{189}$ The niany deceptive trade practices acts that authorize mjunctive relief ${ }^{190}$ also support the constitutionality of equitable remedies for dispar-

hiding behind the other equitable principles put forward in some of the cases"), cert. denied, 317 U.S. 672 (1942).

184. 129 F.2d 227 (3d Cir. 1941), on reh'g, 129 F.2d 232, cert. denied, 317 U.S. 672 (1942).

185. 129 F.2d at 231 ("We are quite willing to repudiate the "waning doctrine that equity will not restrain the trade libel.' ").

186. 129 F.2d at 235-36; see also Maytag Co. v. Meadows Mfg. Co., 35 F.2d 403, 408 (7th Cir. 1929), cert. denied, 281 U.S. 737 (1930); Alliance Sec. Co. v. De Vilbiss Co., 24 F.2d 530, 535-36 (N.D. Ohio 1928), rev'd, 41 F.2d 668 (1930); Rollman Mfg. Co. v. Universal Hardware Works, 238 F. 568 (3d Cir. 1916). McClintock's hornbook on equity presents a good exainple of the pervasive nature of the confusion between defamation and disparagement in equity jurisprudence. See $\mathrm{H}$. MCCLiNTock, supra note 183, 156 (entitled "Defaunation of Property Interests").

187. See D. DoBbS, HANDBOOK ON THE LAW OF REMEDIES $\S 6.7$ (1973) ("If, as is necessary to establish a claim, the plaintiff shows the falsity of the disparaging statennent, and there is no privilege in the defendant to make it, lhe has no legitimate interest in continuing to make such statenients, and an injunction should issue in such a case as freely as if special damages have been shown."); $\mathrm{H}$. MCCLINTOCK, supra note 183, § 156 ("It is to be hoped that the courts will discard the doctrine that they must find some other tort to sustain an injunction against a [disparaging] publication ...."). See generally Pound, Equitable Relief Against Defamation and Injuries to Personality, 29 HARv. L. REv. 640, 640-68 (1916) (arguing that imjunction of disparaging and defamatory speech should be allowed).

188. See, e.g., Advanced Training Sys., Inc. v. Caswell Equip. Co., 352 N.W.2d 1, 11 (Minn. 1984) (upholding temporary and permanent üjunctions over first amendinent objections). State constitutional provisions may also be asserted. See, eg., Citizens' Light, Heat \& Power Co. v. Montgoinery Light \& Water Power Co., 171 F. 553, 556-57 (1909); Wolff v. Harris, 267 Mo. 405, 409, 184 S.W. 1139, 1141 (1916). But see Black \& Yates, 129 F.2d at 231 ("Freedom of discussion of public issues [under state constitution] does not demand lack of 'previous restramt' for injury to private individuals.").

189. Virginia State Bd. of Pharmacy v. Virgima Citizens Consumer Council, 425 U.S. 748, 771 n.24 (1976). Before the Virginia Pharmacy decision, one commentator had concluded that the distinction made in prior restraint cases between "public" and "private" speech would allow restraint of business defamation and disparagement. See Comment, supra note 135, at 101.

190. E.g., 15 U.S.C. $\S \S 52,53$ (1982) (giving the FTC power to enjoin false advertising); 15 U.S.C. $\$ 1125$ (a) (1982) (allowing injunctive rehief for deceptive usage of trademarks); REv. UNIF. Deceptive Trade Practices Act \& 3(a), 7A U.L.A. 265 (1966) (adopted in Colorado, Georgia, Hawaii, Minnesota, Nebraska, New Mexico, Ohio and Oregon); UnIF. Deceptive Trade PracTICES ACT § 3(a), 7A U.L.A. 299 (1964) (adopted in Delaware, Illinois, Maine and Oklahoma). 
ageinent. Thus, there should be no constitutional bar to injunctive rehief for commercial disparageinent.

Noncommercial disparagenent requires a different approach. Disparaging noncoinmercial speech on a matter of public concern is of high first amendment value; the prior restraint doctrine is therefore correctly invoked to prohibit injunctive relief. When, however, the noncommercial speech is on a private matter, a per se rule either allowing or prohibiting injunctive relief may fail to reflect the intricacies of the facts in each case. Therefore, a case by case approach should be adopted, the burden of persuasion being upon the plaintiff to justify the propriety of injunctive relief. ${ }^{191}$

\section{CONCLUSION}

The proper apphication of the first annendment to disparaging speech cannot be gauged by the way the first annendment is applied to defamatory speech. Rather, the policies which underlie that application must be examined. Because the policies that underlie the doctrine of constitutional privilege are not present in the great majority of disparagement actions, the wholesale apphication of constitutional privilege to disparagement is not justified.

The commercial speech doctrine, as recently developed by the Supreme Court, provides a rational and compelling dividing line within the tort of disparagement. Speech that can be cliaracterized as commercial lacks the attributes that constitutional privilege seeks to protect; such speech, therefore, should be left to the common law of disparagement with only minor changes. This conclusion is reinforced by the stringent requirements for recovery in disparagement actions at common law, wlich ensure that liability will only result upon proof of substantial fault. For the minority of disparagements that are noncommercial in nature, constitutional privilege is properly applied to property in tlie public eye.

191. In Mazzocone v. Willing, the court concluded:

We are fully aware that equity cannot enjoin every utterance or publication, whether it be in a trade libel or a defamation case. Each case must stand on its own facts. An injunction will not issue when it is not in the public interest to do so. The pivotal question and its solution depend on the presence or absence of an overriding public interest in the utterance or publication.

246 Pa. Super. 98, 107, 369 A.2d 829, 833 (1976), rev'd, 482 Pa. 377, 393 A.2d 1155 (1978). Cf. Martin v. Reynolds Metals Co., 224 F. Supp. 978 (D. Or. 1963) (awarding injunctive relief against billboard which alleged that an alumina reduction plant was a hazard to the health of both humans and livestock), aff'd, 337 F.2d 790 (9th Cir. 1964); American Broadcasting Cos. v. Smith Cabinet Mfg. Co., 160 Ind. App. 367, 372, 312 N.E.2d 85, 88 (1974) (refusing on first amendment grounds to grant injunction, when disparagement concerned public question, but recognizing propriety of injunctive relief "in a strictly private or personal conflict"). 
Noncommercial speech regarding property not in the public eye, however, should not be accorded special protection.

Rawn Howard Reinhard 